\title{
Effect of Combined Plant Essential Oils on Dermanyssus gallinae: In vitro and In vivo Study
}

\author{
Aziza M. M Amer ${ }^{1 *}$, Mohamed M. Amer' ${ }^{2}$ Hoda M. Mekky ${ }^{3}$ and Hanaa S. Fedawy ${ }^{3}$ \\ ${ }^{I}$ Department of Pharmacology, Faculty Veterinary Medicine, Cairo University, P.O. 12211, Giza, Egypt \\ ${ }^{2}$ Department of Poultry Diseases, Faculty Veterinary Medicine, Cairo University, P.O. 12211, Giza, Egypt \\ ${ }^{3}$ Poultry Diseases Department, Veterinary Research Division, National Research Centre, P.O. 12622, Giza, Egypt \\ *Corresponding author's Email: aziza.mahrous@gmail.com; (iD)RCiD: 0000-0003-0047-8314
}

\begin{abstract}
The present study was carried out to evaluate the effect of plant essential oils on Dermanyssus gallinae $(D$. gallinae). In vitro six groups of red mites, 20 mites in each group were exposed to direct spray of combined plant essential oils (Alisal) in rate of $0.25 \%$ on mites. activity and changes under stereomicroscope showed that sprayed mites completely stopped movements at both 1- and 2- $\mathrm{h}$ after treatment with completely stretched legs and white bead-like spots of oils accumulation on legs and bodies at 1- and 2- h. while, the non-treated mites were active with pale light brown colour. In vivo effect of Allisal to control red mite infestation in laying hens was investigated. In case of drinking water method mite count reduction rate on the bird was $60 \%, 10 \%$, and $0 \%$ as well as $0 \%, 0 \%$ and $10 \%$ in their traps at 4,7 , and 12 days respectively, from the start of treatment in drinking water. While, in spray method mite reduction was $40 \%, 20 \%$, and $10 \%$ on birds and $0 \%, 0 \%$ and $30 \%$ in the traps. On the other hand, water intake, feed intake, general health condition, skin health, and feather condition scores were improved at $4^{\text {th }}$ day post treatment (DPT). Total lesion score at 12 DPT was improved. The present study concluded that in vitro combined plant essential oils have rapid and strong acaricide effect in contact sprays. In vivo, there was obvious improvement in groups treated with plant oils than non-treated group. Drinking water treated birds showed good results than spray treated group. Therefore, it is recommended to use combined plant essential oils in D. gallinae control strategies in poultry.
\end{abstract}

Key words: Acaricides, Chickens mite, Dermanyssus gallinae, Plant essential oils, Red mite.

\section{INTRODUCTION}

Dermanyssus gallinae (D. gallinae) infestation has significant impacts on poultry industry and productivity. Significant economic losses are due to reduction in weight gain and egg production, moreover their role as a disease vector (Flochlay et al., 2017). Also, Blood feeding mite can cause losses due to anemia where layers lose more than 3\% of its blood volume every night. In severe cases hens may die from severe anemia (Van Emous, 2005). The veterinary and human medical impact needs adequate therapeutic measures to control parasites in poultry (Meyer-Kuhling et al., 2007; Roy et al., 2009; Sparagano et al., 2009). Where, D. gallinae is involved in transmission of many pathogenic agents responsible for severe outbreaks in both animals and humans (Chirico and Tauson, 2002; Moro et al., 2009). In a study it's concluded that northern fowl mite infestation (NFM) has negative impact on interior egg quality and hen integument (Vezzoli et al., 2016). D. gallinae life cycle possessed five stages (egg, larva, protonymph, deutonymph, adult) Infestation can triple its numbers in only 10 days where nymphs need a blood meal for metamorphosis and adult females need blood meals for egg maturation. The mites are small and grey in color but may appear red if they have filled with blood after feeding on the bird (Pritchard et al., 2015). Various synthetic contact acaricides such as permethrin, carbaryl, diazinon, dichlorvos are the most used for control D. gallinae infestation lead to drug chemical pollution and the development of resistance (Flochlay et al., 2017). In addition, drug and chemical residues in eggs and meat are an important problem for human health (Cernea, 2006; Kim et al., 2007). So that, there is an urgent need for using of herbal organic pharmaceuticals products as an alternative control measures to avoid drawbacks and maintain a good animal health (Lee et al., 1997; Abbas et al., 2014).

Plant essential oils are rich sources of bioactive components to control of mite infestations (Kim et al., 2004). The main chemical constituent of intact garlic is the amino acid allicin, an alkyl derivative of cysteine alkyl sulfoxide, which may vary from 0.2 to $2.0 \%$ fresh weight (Michahelles, 1974; Lutomski, 1987). Garlic contains at least 100 sulfurcontaining compounds basic to medicinal uses. Allicin represents 70-80\% of the total thiosulfinates (Lawson and Hughes, 1992; Lawson, 1993; Srivastava et al., 1995). Valuable phytochemicals such as phenolic compounds (2554 $\mu \mathrm{g} / \mathrm{g})$, carotenoids $(2.92 \mu \mathrm{g} / \mathrm{g})$, and ascorbic acid $(1798 \mu \mathrm{g} / \mathrm{g})$ are contained in the rosehip seed. Also, it was rich in polyunsaturated fatty acids, linoleic acid (54.05\%), linolenic acid (19.37\%), and phytosterols, mainly $\beta$-sitosterol $(82.1 \%)$ (Ilyasoğlu, 2014). Rapeseed oil is plant-based oil extracted from the seeds of the rapeseed plants contained 
higher levels of total tocopherols and carotenoids. So that, it widely used in animal nutrition (Marčić et al., 2009).

Acaricide/insecticide activity of some plant extracts, oils and active components were examined and used as alternative to the chemical acaricides to control chicken's mite infestation (Kim et al., 2004; Magdaş et al., 2010; George et al. 2010 and 2014).The activity of numerous essential oils were evaluated against adult D. gallinae which collected from poultry using direct contact and fumigation methods, the results showed great effect due to action in the volatile oils (vapour phase) (Kim et al., 2004). In vitro the effect of eleven essential oils using direct contact method was evaluated and the results revealed that the most effective oils were sweet basil, coriander, peppermint and summer savory (Kim et al., 2004; Magdaş et al., 2010). Acaricidal activity of plant bioactive components was evaluated against D. gallinae by contact toxicity to carvacrol and thymol, the author concluded that two components were found to be toxic to D. gallinae with LD50 values of 1 and $3.15 \mu \mathrm{g} / \mathrm{cm}$, respectively (Tabari et al., 2015). Carvacrol-thymol combination in ratio $4: 1$ at $2 \%$ concentration displayed good residual toxicity and was effective against D. gallinae till 14 days post spraying (Masoumi et al., 2016). Garlic essential oil was toxic to T. molitor larva, followed by pupa and adult. Diallyl disulfide was the most toxic induced symptoms of intoxication and necrosis in larva, pupa, and adult of $T$. molitor between 20-40 h after exposure, therefore, garlic essential oil and their compounds have the potential for pest control (Plata-Rueda et al., 2017). The rosehip-seed oil plant oils were efficient natural phytocompounds against the treated larvae of cotton leaf-worm and combination of oils has synergistic action against the $4^{\text {th }}$ larval in star of $S$. littoralis (Mesbah et al., 2006). Rapeseed oil used in spray treatment against spider mites, green peach aphid, pear psylla, summer population of $P$. ulmi and T. urticae resulted in efficacy rate $97.4 \%-84.1 \%$ at 7-11 DPT (Marčić et al., 2009). Antimicrobial activity of the synergistic action of essential oils mixture was also reported (Mesbah et al., 2006; Bassolé and Juliani, 2012; Hyldgaard et al., 2012; Masoumi et al., 2016). Susceptibility of D. gallinae to combined essential oil was carried out by direct contact fumigation or spray to fulfill contact toxicity (Kim et al., 2004; Magdaş et al., 2010; Faghihzadeh Gorji et al., 2014; Rahimian and Sparagano, 2017).

The present study was aimed to evaluate the acaricidal potential of combined plant essential oils (includes garlic, rosehip, rapeseed and polysorbate) in vitro using direct contact method and in vivo through drinking water and direct spray on D. gallinae (red mite) of chickens.

\section{MATERIAL AND METHODS}

\section{Red mite collection}

Five hundred and twenty red mites (D. gallinae) of different stages were collected from naturally infested 5 layer poultry farms. The mites were collected with the aid of a brush in plastic jars and were used for tests within 2 days of collection. Until experiment duration, the mites were kept at $24 \mathrm{C}^{\circ}$ under a photoperiod of 16:8 h light/dark (Magdas et al, 2010). The collected mites were used for testing of efficacy of mixture of vegetable oil extracts (Allisal ${ }^{\circledR}$ ) in vitro and in vivo (Faghihzadeh Gorji et al., 2014; Rahimian and Sparagano, 2017).

\section{Essential oils}

Allisal $^{\circledR}$ is a liquid supplement product of ENVISAL EUROPE BV Vlambloem 85B 3068 JG Rotterdam, Netherlands. It was an aqua suspension of natural plant oils contained garlic oil, rosehip oil, rapeseed oil and polysorbate at concentration of $2.5 \%, 4.2 \%, 4.8 \%$ and $14.0 \%$ respectively. The product was diluted to $0.25 \%$ in water and used for in vivo and in vitro study.

\section{In vitro study}

Grouping and treatment for using direct contact with the mixture of plant oils. Six groups, 20 mites each were transferred to separate glass petri dishes ( 3 replicates) and exposed to the following treatments: Group 1 kept as nontreated control (sprayed with only water). Group 2 was sprayed with $0.25 \%$ plant oils mixture in water. All treated mite groups were observed under stereomicroscope at 1 and $2 \mathrm{~h}$ after direct spray, non-moving mites considered dead, the time for parasite death was recorded and photos taken for comparative evaluation of the acaricidal effect.

\section{In vivo evaluation of plant oil mixture effect on red mite}

Sixty mites infested 45 weeks-old layer hens having marked signs were selected and transferred to our laboratory. Birds were randomly divided into 3 equal groups (1 to 3); 20 hens each. Two hundred mites for each treated group were released for 4 days before start of treatment the average mite count from the first date will be set as $100 \%$ and the following counts will be compared to the first count. Each group was kept in separate cage on cross straw litter, feed on commercial layer ration under natural day light dark time. Hen groups were treated as group 1 kept as control nontreated. Groups 2 and 3 were treated with $0.25 \%$ plant oils mixture for 4 days, followed by 3 days stop of treatment and 
return other 3 days treatment via drinking water and spray, respectively. Four traps were laid in each cage corner and were examined with counting of mite for calculation of counts $\%$ at 4,7 and 12 days from start of treatment and release it again. All groups were subjected to daily observation with recording of comb color, skin color, scape in skin and feather condition for calculation of lesion score. Also, water intake, feed intake and laid egg were considered in observation.

\section{Scoring}

The feather cover on six different body areas (head/neck, breast, vent, wings, back, and tail) was scored using a 0 to 2 scale, with 0 indicating that all body parts were completely feathered, 1 indicating that one or more body areas had damaged feathers or featherless spots $<5 \mathrm{~cm}$ in diameter, and 2 indicating that there were one or more body areas with featherless spots $\geq 5 \mathrm{~cm}$ (Nicol et al., 2009; Welfare Quality, 2009; Vezzoli et al., 2016). The normal layer hens have no lesion (Score 0). The layers with lesions known as one lesion (score 1), two lesions (score 2), three lesions (score 3), four lesions (score 4). The all counted lesions were observed on feather, skin color, scabs and comb color.

\section{Statistical analysis}

The groups were compared at each time point by one-way analysis of variance (ANOVA) in SPSS (Statistics software, 2017) (Allen, 2017). The level of significance of the formal tests was set at 5\%.

\section{RESULTS}

\section{In vitro results of anti-red mites Mite's description}

Mites were directly subjected to treatment and examined under stereomicroscope until complete stop movements and their features were recorded at 1 and 2 hours after treatments (Figure 1). The non-treated mites showed active movement under stereomicroscope with pale light brown color at 1 and 2 hours after treatment (Figures 1A and 1B). The Allisal essential oil sprayed mites with $0.25 \%$ solution were completely stopped movements which considered dead at 1 and 2 hours after treatment with completely stretched legs and white bead like spots of oils accumulation on legs and bodies (Figures $1 \mathrm{C}$ and $1 \mathrm{D}$ ). Results of essential oils contact on D. gallinae at different dose were listed in table (1). For the $0.25 \%$ Allisalessential oils after 1 and $2 \mathrm{~h}$ of contact a strong acaricide effect of $100 \%$ death of red mites at 1 and $2 \mathrm{~h}$ was seen.

\section{In vivo results of anti-red mites}

In vivo effect of Allisal oil to control red mite infestation in laying hens (Table 2). First treatment showed that at the $3^{\text {rd }}$ day post- administration in drinking water mite was reduced to $60 \%$ on bird and $0 \%$ in traps, while in sprays; the mite population was reduced to $40 \%$ on bird and $0 \%$ in trap. At the $7^{\text {th }}$ day ( $1^{\text {st }}$ day of starting $2^{\text {nd }}$ treatment) mite count was reduced to $10 \%$ and $0 \%$ on bird and in trap; respectively, while in spray it was reduced to $20 \%$ and $0 \%$ on birds and in trap; respectively. By the $12^{\text {th }}$ day $\left(2^{\text {nd }}\right.$ day after full treatment course) birds treated via drinking water showed no mite on hens and $10 \%$ in traps, while those spray treated showed $10 \%$ on birds and $30 \%$ in traps. Infested chickens showed dirty dull feather, red spots in pale skin and area free from feather at 0 time, these signs started to improve in treated via drinking water and spray at the $4^{\text {th }}$ day (figure 2) while feathers and skin returned to normal at the $12^{\text {th }}$ day as compared with non-treated. Lesion score (table 3 ) drinking water treated group 2 at the $4^{\text {th }}$ day of treatment showed lower feather, skin color, scabs, comb color and total score $(0.70,0.6,0.70,0.50$ and 2.50) than those of infected non-treated group $1(0.75,0.7,0.85,0.65$ and 2.90$)$, respectively. The spray treatment (group 3$)$ showed slight improvement $(0.70,0.5,0.70$, 0.50 and 2.40). The improvement in feather, skin color, scabs, comb color and total score were the highest at 12 days post-treatment in water $(0.30,0.4,0.30,0.30$ and 1.30 followed by spray $(0.70 \pm, 0.6,0.60,0.50$ and 2.30$)$ compared with non-treated $(0.80,0.8,1.00,0.80$ and 3.45$)$, respectively. At $4^{\text {th }}$ day there is marked improvement in water and feed intake, bird's activity and egg production (quantity and quality) were started to improve in water treated groups than spray and non-treated groups from the $4^{\text {th }}$ day till the $12^{\text {th }}$. In general drinking water treated birds showed suitable general health condition and lower lesion scores than spray treated as compared with non-treated control group.

Table 1. Acaricidal effect of Allisal essential oils against D. gallinae collected from layers farms

\begin{tabular}{llcc}
\hline \multirow{2}{*}{ Treatment } & \multirow{2}{*}{ Dose } & \multicolumn{2}{c}{ Mites Mortality (\%) } \\
\cline { 3 - 4 } & & $\mathbf{1} \mathbf{h .}$ & $\mathbf{2 h s}$ \\
\hline Non treated & Water & 0 & 0 \\
Allisal ${ }^{\circledR}$ Oils & $0.25 \%$ & 100 & 100 \\
\hline
\end{tabular}


Table 2. Effect of Allisal $0.25 \%$ in drinking water and direct spray on red mites count in infested treated hens

\begin{tabular}{|c|c|c|c|c|c|c|c|c|}
\hline \multirow{3}{*}{ Parameter } & \multicolumn{8}{|c|}{ Observation/days } \\
\hline & \multicolumn{4}{|c|}{ Drinking water } & \multicolumn{4}{|c|}{ Spray } \\
\hline & 0 & $4 \mathrm{D}$ & 7 & 12 & 0 & 4 & 7 & 12 \\
\hline Red mites count on birds (\%) & 100 & $60 *$ & 10 & 0 & 100 & 40 & 20 & 10 \\
\hline Red mites count in traps $(\%)$ & 100 & 0 & 0 & 10 & 100 & 0 & 0 & 30 \\
\hline
\end{tabular}

*All numbers are rounded to the nearest ten.

Table 3. Lesion score of Allisal 0.25\%treatment in drinking water and direct spray on red mites in infested laying hens

\begin{tabular}{|c|c|c|c|c|c|c|}
\hline \multirow{3}{*}{ Treatment } & \multirow{3}{*}{$\begin{array}{l}\text { Time/ } \\
\text { days }\end{array}$} & \multicolumn{4}{|c|}{ Lesion } & \multirow{2}{*}{ Total } \\
\hline & & Feather & Skin colour & Scabs & Comb colour & \\
\hline & & Mean* \pm SD** & Mean \pm SD & Mean \pm SD & Mean \pm SD & Mean \pm SD \\
\hline \multirow{4}{*}{ Non-treated } & 0 & $0.65 \pm 0.49$ & $0.6 \pm 0.53$ & $0.75 \pm 0.44$ & $0.55 \pm 0.51$ & $2.50 \pm 0.69$ \\
\hline & 4 & $0.75 \pm 0.45$ & $0.7 \pm 0.49$ & $0.85 \pm 0.37$ & $0.65 \pm 0.49$ & $2.90 \pm 0.79$ \\
\hline & 7 & $0.80 \pm 0.42$ & $0.75 \pm 0.45$ & $0.90 \pm 0.31$ & $0.80 \pm 0.41$ & $3.25 \pm 0.64$ \\
\hline & 12 & $0.80 \pm 0.41$ & $0.8 \pm 0.419$ & $1.00 \pm 0.0$ & $0.80 \pm 0.41$ & $3.45 \pm 0.51$ \\
\hline \multirow{3}{*}{ Drinking water } & 4 & $0.70 \pm 0.48$ & $0.6 \pm 0.52$ & $0.70 \pm 0.48$ & $0.50 \pm 0.53$ & $2.50 \pm 0.53$ \\
\hline & 7 & $0.60 \pm 0.52$ & $0.5 \pm 0.523$ & $0.80 \pm 0.42$ & $0.4 \pm 0.52$ & $2.30 \pm 0.82$ \\
\hline & 12 & $0.30 \pm 0.48$ & $0.4 \pm 0.51$ & $0.30 \pm 0.48$ & $0.30 \pm 0.48$ & $1.30 \pm 1.16$ \\
\hline \multirow{3}{*}{ Spray } & 4 & $0.70 \pm 0.48$ & $0.5 \pm 0.53$ & $0.70 \pm 0.48$ & $0.50 \pm 0.53$ & $2.40 \pm 0.69$ \\
\hline & 7 & $0.60 \pm 0.52$ & $0.5 \pm 0.53$ & $0.60 \pm 0.52$ & $0.60 \pm 0.52$ & $2.40 \pm 0.84$ \\
\hline & 12 & $0.70 \pm 0.48$ & $0.6 \pm 0.52$ & $0.60 \pm 0.51$ & $0.50 \pm 0.53$ & $2.30 \pm 1.05$ \\
\hline
\end{tabular}

*Means: Mean number of birds with lesion/ total birds per group. ** SD: Standard deviation.

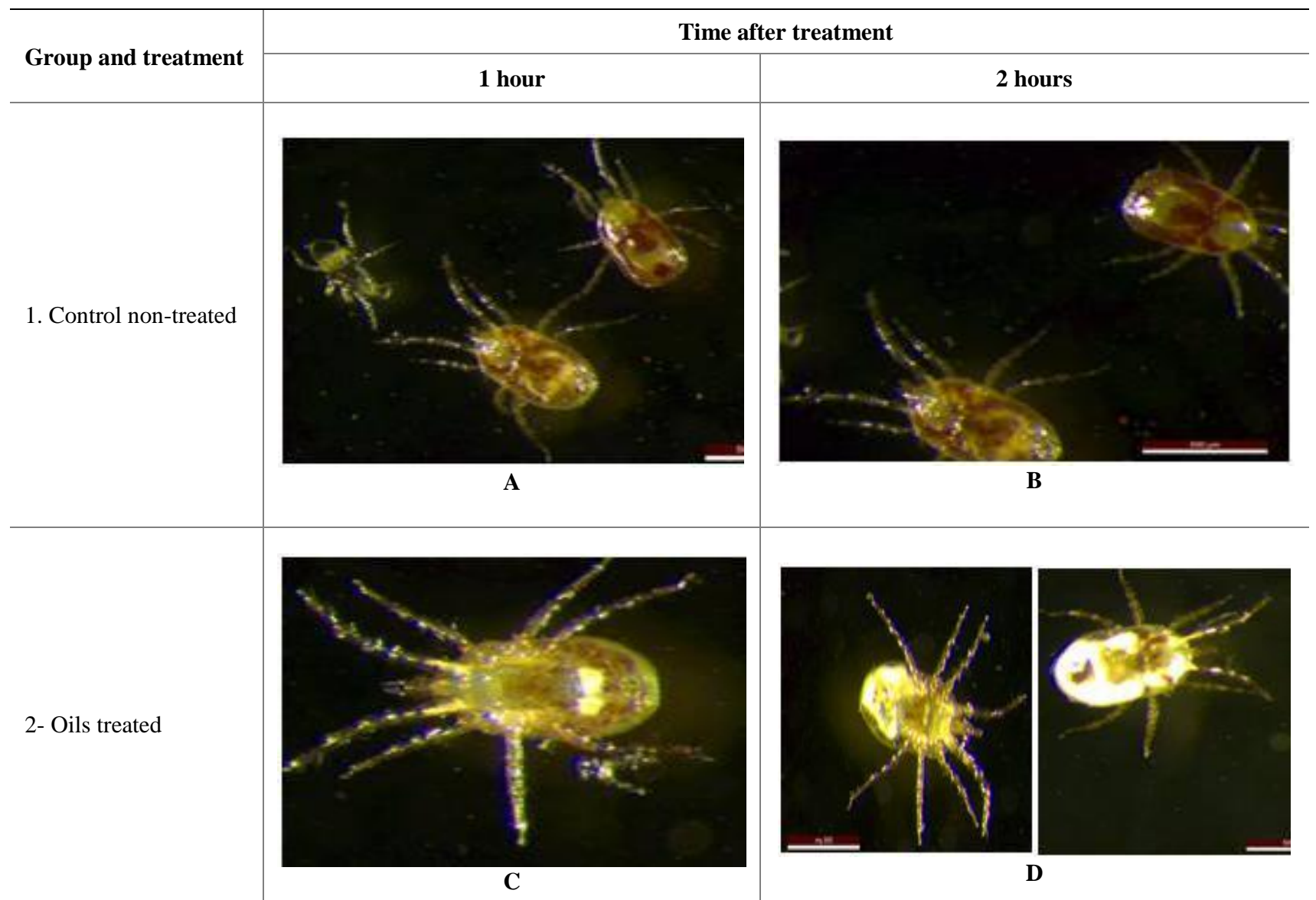

Figure 1. Acaricidal effect of essential oils against D. gallinae collected from layers farms 


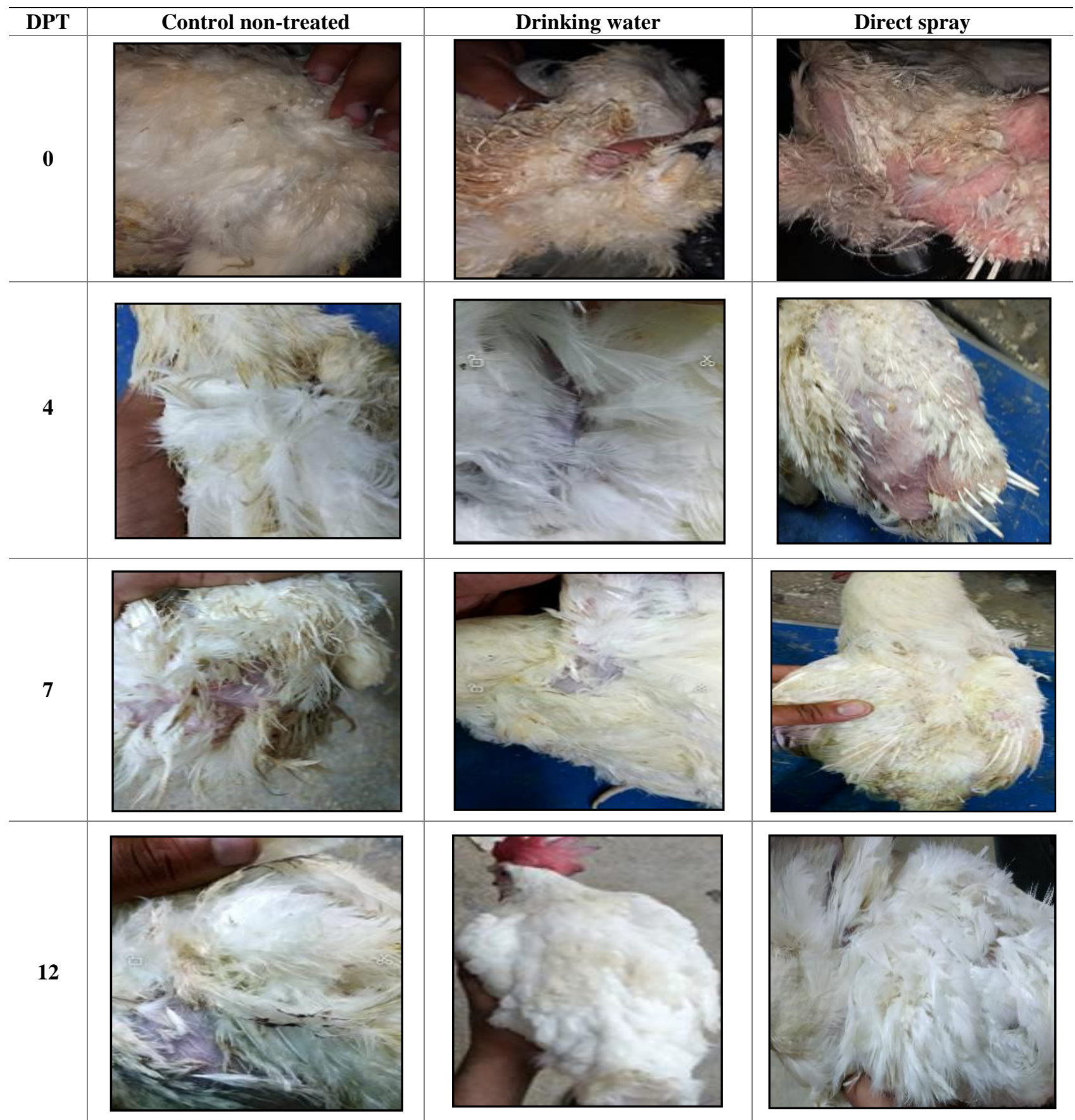

Figure 2. Effect of Allisal essential oil at $0.25 \%$ concentration in drinking water and water direct spray in red mites natural infested laying hens. DPT: Day post treatment. 0: Time before start treatment. 4-, 7- and 12- Days post- treatment

\section{DISCUSSION}

Recently, the susceptibility of field collected D. gallinae from naturally infested commercial chicken houses to essential oil mixture and/or prepared nanoparticles as acaricide was evaluated. The susceptibility of collected D. gallinae to essential oil as acaricide was carried out by direct spray to fulfill contact toxicity (Faghihzadeh Gorji et al., 2014; Rahimian and Sparagano, 2017).

In the present study, we used essential oils mixture (Allisal) which contains garlic oil, rosehip oil and rapeseed oil to evaluate their effect on the chicken's mites in vitro and vivo. As shown in (figure 1 and table 1) results of in vitro essential oils contact on D. gallinae at different doses of the $0.25 \%$ Allisal after 1 and $2 \mathrm{~h}$ of contact were revealed that the non-treated mites showed active movement under stereomicroscope with at 1 and $2 \mathrm{~h}$ after treatment. The Allisal essential oil sprayed mites with $0.25 \%$ solution were completely stopped movements which considered dead at 1 and $2 \mathrm{~h}$ after treatment with completely stretched legs and white bead like spots of oils accumulation on legs and bodies A strong acaricide effect of $100 \%$ death of red mites at 1 and $2 \mathrm{~h}$ was seen. This in accordance with Kim et al. (2004 and 2007) 
and George et al. (2010a, b, 2014) the authors concluded that plant-derived essential oils are shown to have a lethal characteristics, where garlic and thyme oils were the most effective. In the other hand, the synergistic action of essential oil for cuticular penetration was also reported (Tong and Bloomquist, 2013; Tak and Isman, 2015). Where the outer part of the mite exoskeleton, known as the epicuticle, consists of a layer of wax, which further limits water loss, and a cement layer, which protects the cuticle from external abrasion (Pritchard et al., 2015; Flochlay et al., 2017). The hydrophobic nature of the oils can cause mechanical effects on the parasite by disrupting the cuticular waxes and blocking the spiracles, leading to death by water stress or suffocation (Burgess, 2009). On the other hand, some of essential oils can be toxic effect on the insect nervous system (Mills et al., 2004; Lopez and Pascual-Villalobos, 2010) and maybe they have similar effects in other parasites.

The synergistic acaricidal action of essential oil was recorded, and the treated mites showed stop movement and detached legs and abnormal keratin surface of dark brown color at $2 \mathrm{~h}$ (Amagase et al., 2001). High concentration extract of Garlic (Allium sativum) juice and Chrysanthemum (Chrysanthemum cinerariae folium) were found to be effective, against D. gallinae (Maurer et al., 2009).

Strong acaricide effect with $100 \%$ deaths at 1.2 and 3 hours was previously reported by many researchers. Carvacrol (essential oil of Origanum vulgare), garlic extract, cinnamon, eucalyptus and mint extract reduction in mite control with 92\%, 96\%, 66.97, 80.85 and 90.19\%; respectively (Rahimian and Sparagano, 2017). The acaricidal activity of essential oils was tested on movable D. gallinae; regardless of the stage of their development, garlic extract was $96 \%$ effective after two successive sprays (Faghihzadeh Gorji et al., 2014).

Results of in vivo effect of Allisal oil to control red mite infestation in laying hens showed in (table 2 and figure 2) and revealed that in drinking water treated group mites reduction rate on the bird was $60 \%, 10 \%$, and $0 \%$ as well as $0 \%$, $0 \%$ and $10 \%$ in their traps at 4,7, and 12 days respectively, from the start of treatment in drinking water. While, in spray method mite reduction rate was $40 \%, 20 \%$, and $10 \%$ on birds and $0 \%, 0 \%$ and $30 \%$ in the traps. On the other hand, water intake, feed intake, general health condition, skin health, and feather condition scores were improved at $4^{\text {th }}$ (DPT). Total lesion score at 12 (DPT) was improved. Where feathers and skin returned to normal at the $12^{\text {th }}$ day as compared with non-treated group (Table 3). Drinking water treated group showed suitable general health condition and lower lesion scores as well as egg production improvement more than spray treated group.

The improvement in all parameters proved safety of used essential oil mixture in red mite control in poultry. These results may be attributed to efficacy of used oil as antihistaminic, anti-inflammatory, high vitamin E and antioxidant activity. These findings are consistent with the result recorded by (Rabinkov et al., 1998; Miron et al., 2000; Xu et al., 2011; Pillaiyar et al., 2017; Qing, 2017). Moreover, essential oil had been approved as food additives and fall in the category of generally recognized as safe by the US FDA (Bilsland and Strong, 1990). For example, Rapeseed oil is plantbased oil contained higher levels of total tocopherols and carotenoids. So that, it widely used in animal nutrition (Marčić et al., 2009).

\section{CONCLUSION}

From the obtained results its concluded that the treatment with special and formulated essential oil mixture is highly effective for $D$. gallinae when used in drinking water than direct spray $(0.25 \mathrm{ml} /$ liter $)$ as acaricidal. It can be considered as safe recommended alternative to chemical compound used in control strategies of D. gallinae (red mites) in poultry industry.

\section{DECLARATIONS}

\section{Acknowledgment}

Authors are thankful for Prof Dr Gehad G. Mohamed and Sameh H. Ismail, Egypt Nanotechnology Center, Cairo University, El-Sheikh Zayed, 6th October, Giza, Egypt for stereomicroscopic examination and photography of red mites. Also, greatly thankful for ENVISAL EUROPE BV Vlambloem 85B 3068 JG Rotterdam The Netherlands, G. Briesemann (Inventor), G.Blomstee (Assistant) and S. Giesemann (Assistant) for providing the tested material and it is scientific information.

\section{Competing interests}

The authors declare that they have no competing interests.

\section{Author's contributions}

Aziza M. Amer and Mohamed M. Amer designed, planned the study, Hoda M. Mekky and Hanaa S. Fedawy collecting samples. All authors shared performed experimental work, manuscript writing, drafted, revised the manuscript, and approved the final manuscript. 


\section{REFERENCES}

Aazza S, Lyoussi B, Megias C, Cort'es-Giraldo I, Vioque J, Figueiredo AC and Miguel MG (2014). Antioxidant, anti-inflammatory and antiproliferative activities of Moroccan commercial essential oils. Natural Product Communications, 9(4): 587-594. DOI: https://doi.org/10.1177/1934578X1400900442

Abbas RZ, Colwell DD, Iqbal Z and Khan A (2014). Acaricidal drug resistance in poultry red mite (Dermanyssus gallinae) and approaches to its management. World's Poultry Science Journal, 70:113- 124. DOI: https://doi.org/10.1017/S0043933914000105

Ali B, Al-Wabel NA, Shams S, Ahamad A, Khan AS and Anwar F (2015). Essential oils used in aromatherapy: A systemic review. Asian Pacific Journal of Tropical Biomedicine, 5(8): 601- 611. DOI: https://doi.org/10.1016/i.apjtb.2015.05.007

Allen M (2017). Analysis of Variance (ANOVA) In: The SAGE Encyclopedia of Communication Research Methods. DOI https://dx.doi.org/10.4135/9781483381411.n15

Amagase H, Petesch BL, Matsuura H, Kasuga S and Itakura Y (2001). Intake of Garlic and Its Components. The Journal of Nutrition, 131: 955S-962S. DOI:https://doi.org/10.1093/jn/131.3.955S

Bassolé IHN and Juliani HR (2012). Essential oils in combination and their antimicrobial properties. Molecules, 17: 3989- 4006. DOI: https://doi.org/10.3390/molecules17043989

Burgess IF (2009). The mode of action of dimeticone 4\% lotion against head lice, Pediculus capitis. BMC Pharmacology, 9: 3 DOI: https://doi.org/10.1186/1471-2210-9-3

Cernea LC, Şuteu E, Cernea M, Lefkaditis M and Cozma V (2006). Realization of an experimental model for in vitro testing of the acaricidal effect of the vegetal extracts. Scientia Parasitologica, 7(1-2):35- 40. DOI: http://www.zooparaz.net/scientia/2006 07 01/07-Cernea\%20Cristina-2.pdf

Chirico J and Tauson R (2002). Traps containing acaricides for the control of Dermanyssus gallinae. Veterinary Parasitology 110 (1-2): 109-116. DOI: https://doi.org/10.1016/S0304-4017(02)00310-2

Communication Research Methods SAGE Publications, Inc, Thousand Oaks. pp 1-6. DOI: http://dx.doi.org/10.4135/9781483381411.n15

Da Silva SMM, Costa CRR, Gelfuso GM, Guerra ENS, Nóbrega YKDM, Gomes SM, Pic-Taylor A, Fonseca-Bazzo YM, Silveira D and Magalhães PDO (2019). Wound healing effect of essential oil extracted from Eugenia Dysenterica DC (Myrtaceae) leaves. Molecules, 24, 2-16. DOI:https://doi.org/10.3390/molecules24010002

Faghihzadeh Gorji S, and Rajabloo M (2014). The field efficacy of garlic extract against Dermanyssus gallinae in layer farms of Babol, Iran. Parasitology Research, 113:1209-1213. DOI:https://doi.org/10.1007/s00436-014-3759-2

Flochlay A, Thomas E and Sparagano O (2017). Poultry red mite (Dermanyssus gallinae) infestation: A broad impact parasitological disease that still remains a significant challenge for the egg-laying industry in Europe. Parasites \& Vectors, 10 (1):357. DOI:https://doi.org/10.1186/s13071-017$\underline{2292-4}$

George DR, Finn RD, Graham KM and Sparagano OA (2014). Present and future potential of plant-derived products to control arthropods of veterinary and medical significance. Parasites and Vectors, 7: 28. DOI: https://doi.org/10.1186/1756-3305-7-28

George DR, Olatunji G, Guy JH and Sparagano OAE (2010). Effect of plant essential oils as acaricides against the poultry red mite, Dermanyssus gallinae, with special focus on exposure time. Veterinary Parasitology, 169 (1-2): 222-225. DOI: https://doi.org/10.1016/j.vetpar.2009.12.038

Hyldgaard M, Mygind T and Meyer RL (2012). Essential oils in food preservation: mode of action, synergies, and interactions with food matrix components. Frontiers in Microbiology, 3:12. DOI: 10.3389/fmicb.2012.00012

Ilyasoğlu H (2014). Characterization of Rosehip (Rosa canina L.) Seed and Seed Oil. International Journal of Food Properties, 17(7): 1591-1598. DOI: https://doi.org/10.1080/10942912.2013.777075.

İlyasoğlu $\mathrm{H}$ and Arpa TE (2017). Effect of brewing conditions on antioxidant properties of rosehip tea beverage: study by response surface methodology. Journal of Food Science and Technology, 54(11): 3737-3743. DOI:10.1007/s13197-017-2794-2

Kim SI, Na YE, Yi JH, Kim BS and Ahn YJ (2007). Contact and fumigant toxicity of oriental medicinal plant extracts against Dermanyssus gallinae (Acari: Dermanyssidae). Veterinary Parasitology, 145:377-382. DOI: 10.1016/j.vetpar.2006.12.021

Kim SI, Yi JH, Tak JH and Ahn YJ (2004). Acaricidal activity of plant essential oils against Dermanyssus gallinae (Acari: Dermanyssidae). Veterinary Parasitology, 120: 297- 304.DOI: https://doi.org/10.1016/j.vetpar.2003.12.016

Lawson LD (1993). Bioactive organosulfur compound of garlic and garlic products: role in reducing blood lipids. In: Kinghorn AD, Balandrin MF, editors. Human medicinal agents from plants. Washington: American Chemical Society, p.306- 330, and ACS Symposium Series, n. 534 DOI: 10.1021/bk-1993-0534.ch021

Lawson LD and Hughes BG (1992). Characterization of the formation of allicin and other thiosulfinates from garlic. Planta Medica, 58: 345- 350. DOI: $10.1055 / \mathrm{s}-2006-961482$.

Lee S, Tsao R, Peterson C and Coats JR (1997). Insecticidal activity of monoterpenoids to Western corn rootworm (Coleoptera: Chrysomelidae), twospotted spider mite (Acari: Tetranychidae) and house fly (Diptera: Muscidae). Journal of Economic Entomology, 90: 883-892. DOI:10.1093/jee/90.4.883

Lopez MD and Pascual-Villalobos MJ (2010). Mode of inhibition of acetylcholinesterase by monoterpenoids and implications for pest control. Industrial Crops and Products, 31: 284-288. DOI: https://doi.org/10.1016/j.indcrop.2009.11.005

Lutomski J (1987). Components and biological properties of some Allium species. Poznan: Institute of the Medicinal Plants., pp. 1-58. In Singh VK and Singh DK (2008). Pharmacological Effects of Garlic (Allium sativum L.) ARBS. Annual Review of Biomedical Sciences, 10: 6-26. DOI:

10.5016/1806-8774.2008.v10p6

Magdas M, Cernea M, Baciu H and Şuteu E (2010). Acaricidal effect of eleven essential oils against the poultry red mite Dermanyssus gallinae (Acari: Dermanyssidae). Scientia Parasitologica, 11(2): 71-75. DOI:http://www.zooparaz.net/scientia/2010_11_02/sp2010-pp071-075\%20\%20Magdas.pdf

Marčić D, Perić P, Prijović M and Ogurlić I (2009). Field and greenhouse evaluation of rapeseed spray oil against spider mites, green peach aphid and pear psylla in Serbia. Bulletin of Insectology, 62 (2): 159-167 DOI: http://www.bulletinofinsectology.org/pdfarticles/vol62-2009-159167 marcic.pdf

Masoumi F, Youssefi MR and Tabari MA (2016). Combination of carvacrol and thymol against the poultry red mite (Dermanyssus gallinae). Parasitology Research, 115(11): 4239- 4243. DOI:https://doi.org/10.1007/s00436-016-5201-4

Maurer V, Perler E and Heckendorn F (2009). In vitro efficacies of oils, silicas and plant preparations against the poultry red mite Dermanyssus gallinae. Experimental and Applied Acarology, 48: 3- 41. DOI:https://doi.org/10.1007/s10493-009-9254-2

Mesbah HA, Mourad AK and Rokaia AZ (2006). Efficacy of some plant oils alone and/or combined with different insecticides on the cotton leaf-worm Spodoptera littoralis (Boisd.) (Lepidoptera: Noctuidae) in Egypt. Communications in Agricultural and Applied Biological Sciences, 71: 305328. PMID: 17385497. DOI: https: http://europepmc.org/article/med/17385497

Meyer-Kuhling B, Pfister K, Muller-Lindloff J and Heine J (2007). Field efficacy of phoxim 50\% (ByeMite) against the poultry red mite Dermanyssus 
gallinae in battery cages stocked with laying hens. Veterinary Parasitology, $147 \quad(3-4): \quad 289-296$. DOI:https://doi.org/10.1016/j.vetpar.2007.04.012

Mills C, Cleary BJ, Gilmer JF and Walsh JJ (2004). Inhibition of acetylcholinesterase by tea tree oil. The Journal of Pharmacy and Pharmacology, 56: 375-379. DOI: https://doi.org/10.1211/0022357022773

Miron T, Rabinkov A, Mirelman D, Wilchek M and Weiner L (2000). The Mode of Action of Allicin: Its Ready Permeability through Phospholipid Membranes May Contribute to Its Biological Activity. Biochimica et Biophysica Acta, 1463: 20-30. DOI:https://doi.org/10.1016/s00052736(99)00174-1

Moro CV, Thioulouse J, Chauve C, Normand P and Zenner L (2009). Bacterial taxa associated with the hematophagous mite Dermanyssus gallinae detected by 16S rRNA PCR amplification and TTGE fingerprinting. Research in Microbiology, 160: 63-70. DOI:http://pbil.univlyon1.fr/JTHome/ref/ValienteRIM2009.pdf

Murbach Teles Andrade BF, Conti BJ, Santiago KB, Fernandes J'unior A and Sforcin JM (2014). Cymbopogon martinii essential oil and geraniol at noncytotoxic concentrations exerted immunomodulatory/anti-inflammatory effects in human monocytes. Journal of Pharmacy and Pharmacology, 66(10): 1491-1496. DOI:https://doi.org/10.1111/jphp.12278

Nicol CJ, Caplen G, Edgar J and Browne WJ (2009). Associations between welfare indicators and environmental choice in laying hens. Animal Behavior, 78, 413 424. DOI:http://dx.doi.org/10.1016/j.anbehav.2009.05.016

Pillaiyar T, Manickam M and Namasivayam V (2017). Skin whitening agents: Medicinal chemistry perspective of tyrosinase inhibitors. Journal of Enzyme Inhibition and Medicinal Chemistry, 32: 403-425. DOI:https://doi.org/10.1080/14756366.2016.1256882

Plata-Rueda A, Martínez LC, Dos Santos MH, Fernandes FL, Wilcken CF, Soares MA, Serrão JE and Zanuncio JC (2017). Insecticidal activity of garlic essential oil and their constituents against the mealworm beetle, Tenebrio molitor Linnaeus (Coleoptera: Tenebrionidae). Science Report, 7: 46406. DOI:https://doi.org/10.1038/srep46406.

Pritchard J, Kuster T, Sparagano O and Tomley F (2015): Understanding the biology and control of the poultry red mite Dermanyssus gallinae: a review. Avian Pathology, 44(3): 143-153. DOI: 10.1080/03079457.2015.1030589.

Qing C (2017). The molecular biology in wound healing \& non-healing wound. Chinese Journal of Traumatology, 20: 189- 193.DOI https://doi.org/10.1016/j.cjtee.2017.06.001

Rabinkov A, Miron T, Konstantinovski L, Wichek M, Mirelman D and Weiner L (1998). The Mode of Action of Allic: Trapping of Radicals and Interaction with Thiol-Containing Proteins. Biochimica et Biophysica Acta, 1379: 233-234. DOI: https://doi.org/10.1016/s03044165(97)00104-9

Rahimian S and Sparagano OAE (2017). Dermanyssus gallinae status in iran: an emerging problem. $3^{\text {rd }}$ Cost Conference, 20-21 September, Oeiras, Portugal. Avilable at: DOI:https://www.coremi.eu/fileadmin/documents_organicresearch/coremi/COREMI_3rd_Conference_Portugal_Final.pdf

Roy L, Chauve C, Delaporte J, Inizan G and Buronfosse T (2009). Exploration of the susceptibility of AChE from the poultry red mite Dermanyssus gallinae (Acari: Mesostigmata) to organophosphates in field isolates from France. Experimental and Applied Acarology, 48: 19-30. Available at: DOI:https://link.springer.com/content/pdf/10.1007\%2F978-90-481-2731-3 4.pdf

Sparagano O, Pavlićević A, Murano T, Camarda A, Sahibi H, Kilpinen O, Mul M, van Emous E, le Bouquin S, Hoel S and Cafiero MA (2009). Prevalence and key figures for the poultry red mite Dermanyssus gallinae infections in poultry farm systems. Experimental and Applied Acarology, 48:3-10. DOI: https://doi.org/10.1007/s10493-008-9233-z

Srivastava KC, Bordia A and Verma SK (1995). Garlic (Allium sativum) for disease prevention. South African Journal of Science, 91:68-77. DOI: https://hdl.handle.net/10520/AJA00382353_5167

Tabari M A, Youssefi MR, Barimani A and Araghi A (2015). Carvacrol as a potent natural acaricide against Dermanyssus gallinae. Parasitology Research, 114(10): 3801-3806. DOI: https://doi.org/10.1007/s00436-015-4610-0

Tak J-H and Isman MB (2015). Enhanced cuticular penetration as the mechanism for synergy of insecticidal constituents of rosemary essential oil in Trichoplusia ni. Scientific Reports, 5:12690. DOI:https://doi.org/10.1038/srep12690.

Tong F and Bloomquist JR (2013). Plant essential oils affect the toxicities of carbaryl and permethrin against Aedes aegypti (Diptera: Culicidae). Journal of Medical Entomology,50: 826-832. DOI:https://doi.org/10.1603/me13002

Van Emous R (2005). Wage war against the red mite. Poultry International, 44: 26-33. https://www.researchgate.net/publication/273061487

Vezzoli G, Annie J, King JA and Mench AJ (2016). The effect of northern fowl mite (Ornithonyssus sylviarum) infestation on hen physiology, physical condition, and egg quality. Poultry Science, 95:1042-1049. DOI: http://dx.doi.org/10.3382/ps/pew027

Welfare Quality® (2009). Welfare Quality ${ }^{\circledR}$ Assessment Protocol for Poultry (Broilers, Laying Hens) Welfare Quality® Consortium Lelystad, Netherlands.

Xu J, Zhou X, Deng Q, Huang Q, Yang J and Huang F (2011). Rapeseed oil forfied with micronutrients reduces atherosclerosis risk factors in rats fed a high-fat diet. Lipids in Health and Diseases, 10: 96. DOI: http://dx.doi.org/10.1186/1476-511X-10-96 